\title{
On Energy Dependence, Current Account Deficit and Population in Turkey
}

\author{
Cem Berk ${ }^{1}$, Kazim Oguz Cin ${ }^{2}$ \\ ${ }^{1}$ Department of Accounting and Finance, Istanbul Arel University, Istanbul, Turkey \\ ${ }^{2}$ Granite Services International, Istanbul, Turkey \\ Email:cemberk@arel.edu.tr, KazimOguz.Cin@ge.com
}

How to cite this paper: Berk, C. and Cin, K.O. (2018) On Energy Dependence, Current Account Deficit and Population in Turkey. Open Journal of Business and Management, 6, 183-192.

https://doi.org/10.4236/ojbm.2018.61012

Received: December 29, 2017

Accepted: January 26, 2018

Published: January 29, 2018

Copyright $\odot 2018$ by authors and Scientific Research Publishing Inc. This work is licensed under the Creative Commons Attribution International License (CC BY 4.0).

http://creativecommons.org/licenses/by/4.0/

\begin{abstract}
Energy industry is one of the most important elements in the development of countries. Energy dependence occurs when the energy produced in a country by using its own resources is unable to meet the consumption where the lacking amount needs to be imported. This might lead to significant effects in the current account of an economy. However in addition to non-renewable energy sources (such as natural gas, and oil), alternative production is available in Turkey (such as wind, solar, geothermal, biomass, and hydrogen) as well as projects to install nuclear plants. The population in Turkey on the other hand is unlikely to decrease even in the long term. In the Turkish economy, energy industry might affect the economic growth, trade deficit and population growth. This is proven by various studies explained in the summary of literature section of this paper. In this paper, energy consumption, population and trade deficit are analyzed in a data sample from a period of 1970 until 2014. The data is obtained from World Bank and Central Bank of Turkey. The relationship between energy consumption, population and current account deficit is analyzed by using Granger causality analysis, Augmented Dickey Fuller (ADF) Unit Roots Test", Vector Autoregression (VAR) and Vector Error Correction Models (VECM). As a result of the "Granger Causaility Analysis", it is determined that there is a two way relationship between energy consumption and trade deficit and one way relationship between population and trade deficit and between population and energy consumption. Therefore energy production strategies including the use of existing reserves and alternative energy sources are suggested for sustainable economic growth.
\end{abstract}

\section{Keywords}

Economy, Energy Dependence, Population, Foreign Trade Deficit 


\section{Introduction}

Achieving economic development for developing countries with energy imports requires the use of national energy resources and alternative energy for growth and employment. The countries with energy dependence need to effectively use the energy resources to lower trade deficit and achieve employment and economic growth criteria.

It is possible for dependent countries to use alternative energy sources. A sustainable growth is achievable by supporting energy investments. If there are more incentives on alternative energy sources, energy imports would decrease. This paper covers the topics of energy dependence and current account deficit and also population.

The current account deficit has been a chronical problem in Turkish economy. Moreover, Turkish economy is in a middle income trap, not being able to generate intellectual products to reach the level of developed economies. When the current account is analyzed, it is seen that the energy import is close to the amount of deficit. Therefore this paper has a focus on energy dependence and its implications on current account deficit.

Another aspect of current account deficit and energy is population. Turkish population has a reduced growth in population but the population has been in an increasing trend. Therefore the effects of population on energy and current account are also available in this research. The study is unique to combine these three elements, because there are limited researches applying this methodology.

The remainder of the paper is organized as follows. The second section is the literature review, where some of the relevant works in the literature are discussed. In the third section, research methodology is given. The fourth section is the analysis of the data. Finally in the fifth section, a general discussion on the paper and concluding remarks are available.

\section{Summary of Literature}

Some of the relevant works in the literature are given in Table 1. According to the findings, most authors study the causality between GDP and Energy consumption. The literature however is limited with studies including population. Most of the findings of the literature reveals the existence of a causality however the direction is different in the studies. In most of the research findings the direction is from energy consumption to GDP, but there are some findings with opposite direction or two way causality.

Similar studies are available in international literature. Narayan and Smyth studied Australian economy using annual data for the period 1996-1999. The results of the ECM analysis point out that there is one way causality from GDP to employment and electricity consumption per capita in the short run. In the long run, there is one way causality from employment and GDP to electricity consumption per capita [5].

Nasiru et al. detected cointegration between oil consumption and GDP using annual data in Vietnam for the period 1980-2011. As a result of Granger 
Table 1. Summary of literature.

\begin{tabular}{ccc}
\hline Author & Research Period & Finding \\
\hline Vlahinic \& Jakovac & $1952-1971$ & $\begin{array}{c}\text { One way causality from Energy Consump- } \\
\text { tion to GDP [12] }\end{array}$ \\
Kraft \& Kraft & $1947-1974$ & One way causality from GDP to Energy \\
Consumption [3]
\end{tabular}

causality test, there is one way causality from oil consumption to GDP [6]. Nonejad and Fathis analyzed Iranian economy using annual data. Cointegration and VECM points out that there is one way causality from capital stock and employment to GDP and two way causality between GDP and energy consumption [7]. Park and Yoo studied Malaysian economy using annual data. They detect two way causality between oil consumption and GDP using cointegration and VECM [8].

Stambuli made a research in Tanzanian economy for the period 1972-2010 using annual data. According to the results, there is one way causality from oil consumption to oil price and from GDP to oil consumption and oil price. Cointegration and VECM are used in the research [10].

Vlahinicand Jokavac studied Crotian economy using annual data for the period 1971-2010. In the study, there is two way causality between energy consumption and GDP in the short run. In the long run, there is one way causality from energy consumption and GDP. JJ Cointeration analysis and VECM are used in this research [12].

\section{Data and Methodology}

The data analysis includes Granger Causality, Augmented Dickey Fuller Unit Root Test, Vector Autoregression (VAR) and Vector Error Correction Model (VECM). Annual data is used for the period 1970-2014. The data include population, current account deficit, and energy consumption in Turkey and is obtained from World Bank and Central Bank of Turkey. The data is readily available in the online databases of these institutions. Therefore the data is obtained and transferred to a spread sheet to be used in the analysis. The software used for this analysis is E-views 9.5. 
The variables are checked to see whether they are stationary. Figure 1 shows that the variables are not stationary in level.

Augmented Dickey Fuller test at 5\% level of significance is chosen for the analysis. Table 2 shows that all of the variables are stationary when their first differences are used.

According to the analysis, the variables are not stationary in level. Therefore their first difference is used for the analysis. Figure 2 shows the graphical representation of data by their first differences.

Before the Vector Autoregression proper lag length needs to be determined. Lag Length selection criteria are first analyzed. According to Table 3, all criteria except Schwarz suggest 3 lags. Therefore the study is analyzed with three lags.

Vector autoregression (VAR) analysis includes 3 different regressions. The dependent variables are current account deficit, energy consumption and population. The regressions include 3 lags of each individual variable as independent variables. The VAR coefficients are given in Table 4.

For the short term analysis Vector Error Correction model is required. The results of the analysis are presented in Table 5. For the system to work, the error

\section{Current Account Deficit}

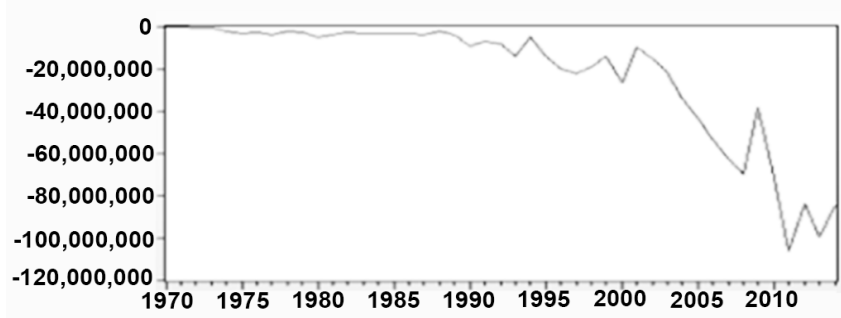

(a)

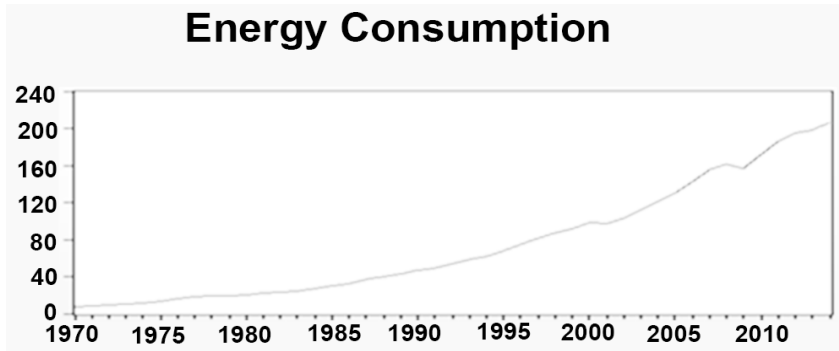

(b)

\section{Population}

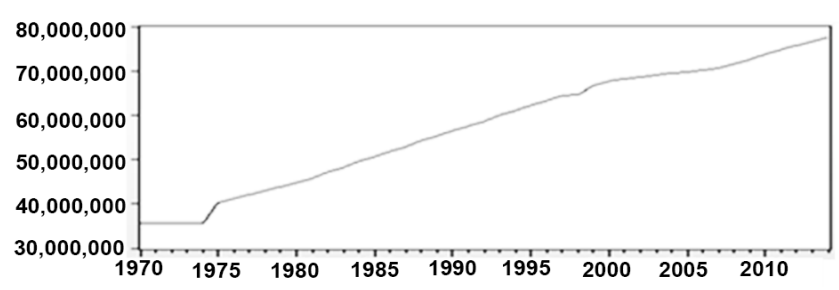

(c)

Figure 1. Graphical representation of data. Source: World Bank, Central Bank of Turkey. 


\section{Current Account Deficit}

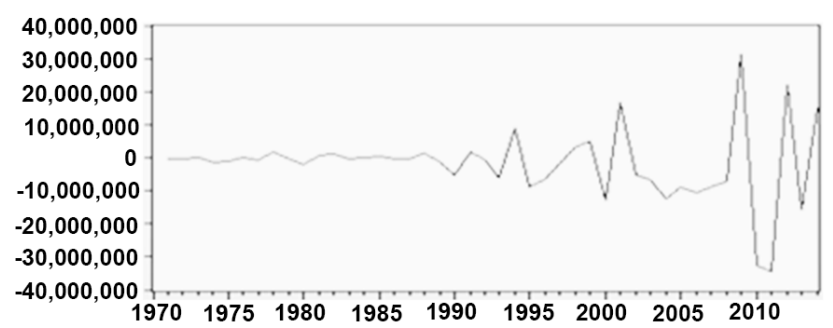

(a)

\section{Energy Consumption}

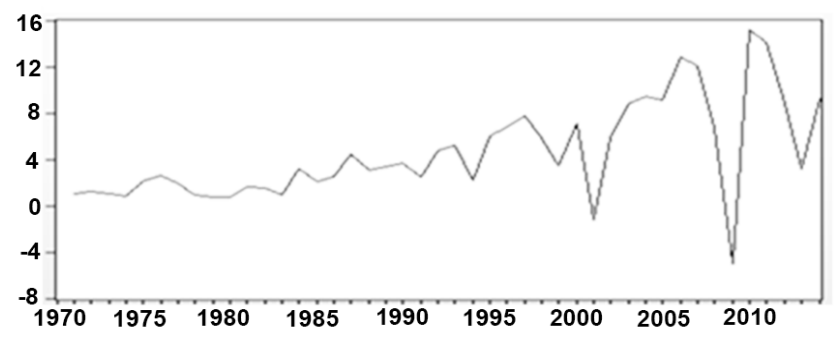

(b)

\section{Population}

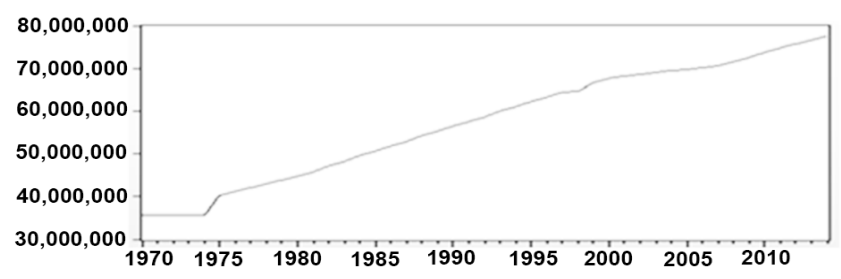

(c)

Figure 2. Graphical representation of data by their first differences. Source: World Bank, Central Bank of Turkey.

Table 2. ADF test results.

\begin{tabular}{cccc}
\hline Constant \& Trend & $\begin{array}{c}\text { D (Current Account } \\
\text { Deficit) }\end{array}$ & $\begin{array}{c}\text { D (Energy } \\
\text { Consumption) }\end{array}$ & D(Population) \\
\hline No Constant \& No Trend & Stationary & Stationary & Stationary \\
Constant \& Trend & Stationary & Stationary & Stationary \\
Constant Only & Stationary & Stationary & Stationary \\
\hline
\end{tabular}

Table 3. Lag length selection.

\begin{tabular}{cc}
\hline Criterion & Lag Length Suggested \\
\hline LogL & 3 \\
LR & 3 \\
FPE & 3 \\
AIC & 3 \\
SC & 1 \\
HQ & 3 \\
\hline
\end{tabular}


Table 4. Vector autoregression results.

\begin{tabular}{cccc}
\hline Coefficient & $\begin{array}{c}\text { Current Account } \\
\text { Deficit }\end{array}$ & $\begin{array}{c}\text { Energy } \\
\text { Consumption }\end{array}$ & Population \\
\hline Current Account Deficit (-1) & 0.4089 & -0.0046 & 0.0065 \\
Current Account Deficit (-2) & 0.1016 & 0.0360 & -0.0028 \\
Current Account Deficit (-3) & 0.3247 & 0.0011 & -0.0123 \\
Energy Consumption (-1) & 0.7210 & 0.6098 & 0.0980 \\
Energy Consumption (-2) & 0.8640 & -0.0227 & -0.2726 \\
Energy Consumption (-3) & 0.0337 & 0.0285 & 0.1898 \\
Population (-1) & 0.7898 & 0.8275 & 0.9664 \\
Population (-2) & 0.6033 & -0.2948 & 0.0278 \\
Population $(-3)$ & -1.9377 & -0.4525 & -0.0174 \\
\hline
\end{tabular}

Table 5. Vector error correction model results. (Dependent variable: Population).

\begin{tabular}{ccc}
\hline Variable & Coefficient & Probability \\
\hline Error Terms & -0.8371 & 0 \\
Energy Consumption & 1.0078 & 0 \\
Current Account Deficit & -0.3356 & 0 \\
\hline
\end{tabular}

terms coefficient should be between 0 and -1 . In our model, there is no such problem. In addition the variables should be statistically significant. This is fulfilled by probability values being less than 0.05 . In our analysis, the variables are statistically significant.

\section{Findings and Discussion}

Granger Causality analysis is used to see whether there is a statistically significant relationship and if there is a relationship the analysis shows the direction by determining dependent and independent variables [14]. The results of the analysis are available in Table 6.

When the dependent variable is current account deficit, the probability values of energy consumption and population are less than 5\%. This means both energy consumption and population individually Granger Cause current account deficit. Energy consumption causes current account deficit, because Turkey needs to import natural gas due to lack of domestic sources. Similarly although there is a tendency of decrease in the growth rate of population, population will keep increasing in Turkey. But according to the analysis, these increases do not generate enough GDP growth due to lack of capacity to employ this workforce. Therefore increase in population would mean more current account deficit.

In the second equation, dependent variable is energy consumption. The probability values of both current account deficit and population are less than $5 \%$. This means they both individually Granger cause energy consumption. 
Table 6. Granger causality.

\begin{tabular}{cc}
\hline Variable & Probability \\
\hline Dependent Variable: Current Account Deficit & \\
Energy Consumption & 0.0187 \\
Population & 0.0202 \\
Dependent Variable: Energy Consumption & \\
Current Account Deficit & 0.0180 \\
Population & 0.0202 \\
Dependent Variable: Population & \\
Current Account Deficit & 0.5001 \\
Energy Consumption & 0.0656 \\
\hline
\end{tabular}

Another result is there is a two way Granger causality between energy consumption and current account deficit. This is because we already mentioned in the previous paragraph that energy consumption granger causes current account deficit. But opposite direction is also valid. When there is an increase in current account deficit, increased energy imports lead to less lead to less energy efficiency that make most use of energy. Also increased population would increase energy consumption because more energy is needed and energy efficiency projects are not that much effective in the short run.

The dependent variable of the last equation is population. The probability value of current account deficit is $50 \%$ which is way larger than $5 \%$. This means current account deficit do not granger cause population. The increase in population can't be explained with current account deficit. The probability value of energy consumption is also $6.5 \%$ which is more than $5 \%$. This means under $5 \%$ level of significance energy consumption doesn't Granger cause population. Population also can't be explained with energy consumption.

The sustainable development in Turkey can be obtained by controlling current account deficit which requires accurate population and energy efficiency policy. Lack of new technology and population growth increase energy dependence of Turkey.

Most of the energy used in the World is primary energy sources such as oil, coal and gas. Renewable energy has a much lower share. Turkey doesn't have enough primary energy sources, so this leads to a current account deficit problem.

In this research, energy consumption, population and current account deficit is analyzed for the period 1970-2014. As a result there is two way causality between current account deficit and energy consumption, one way causality between population and energy consumption and another one way causality between population and current account deficit. It is also known from the previous works in this field that import based energy consumption increases current account deficit. 
Because of the lack of primary energy sources, alternative energy sources may be used. For Turkey, wind, solar and geothermal energy sources may be used. Renewable energy may be used to decrease current account deficit. However there are barriers such as high costs and lack of adequate incentives.

Turkey is dependent on energy consumption to other countries as most of the consumption is from gas. In addition the change in energy prices, also affects current account deficit. Therefore reducing energy dependence requires long term strategies which lead to less energy imports.

However, energy import rate in Turkey keeps increasing which leads to sustainability problem in the long run. Possible solutions are, to use existing energy reserves and alternative energy sources and to reevaluate population policy. This may lead to decrease in oil and gas imports.

\section{Conclusions}

Turkey doesn't have enough quality and quantity of underground riches. (Oil, natural gas, mines etc.) This forced energy managers in Turkey to import in order to meet socioeconomic necessities of the World. Turkey has projects to research more and increase the production of already existing energy resources. However it doesn't have the time to wait for domestic energy production to meet local energy demand. Therefore most of the energy needed for socioeconomic life is met by imports. The energy dependence in Turkey during the last decade has been around $60 \%$ and $65 \%$.

This is an important pressure on the economy and current account deficit especially when the energy prices increase. The paper discusses the relationship between the energy consumption and current account deficit. The increase in energy consumption leads to increase in energy imports which lead to current account deficit. The incentive on renewable energy is one of the most critical issues in reducing the current account deficit.

The wind energy has rapidly developed during the last decade. Solar energy technology is getting cheaper and can contribute to lower current account deficit in the following years. Geothermal energy is also used and the electricity produced can be sold to the system with high prices. The incentives in Turkey include sales guarantee, import without customs duties, VAT exemption and tax credit.

The amount of energy produced by alternative energy resources when hydroelectric power plants with dams are included are roughly $25 \%$. Savings on energy, cogeneration and trigeneration systems contribute to energy efficiency. There are also attempts to use energy efficient light bulbs, and white goods in houses.

The most important imports affecting current account deficit are oil, coal and natural gas. Turkey is mostly dependant on Russia in these goods. Russia exports these commodities directly to Turkey bypassing Ukraine. Turkey tries to lower this dependence by agreements with Algeria, Nigeria, Qatar and Iran. There are 
also agreements to transfer the natural gas from Azerbaijan and Israel to Europe. Gas prices are in a decreasing trend due to advances in shale gas technology. The pressure of Russia on European countries by the natural gas started to decrease as the prices get lower.

It is interesting that Turkey doesn't have oil reserves while the neighboring countries of Turkey have it. Therefore there are attempts to find reserves in northeast and south of Turkey and in Black Sea. This research is done to reduce the oil pressure in current account deficit. There is less country dependence in oil than natural gas as it can be bought from any country where it is cheaper. However the price of oil is volatile in the market. As the oil prices get lower, the current account deficit also decreases.

Coal prices are also decreasing. High calorie coal can be imported cheaper than oil and natural gas. However coal has environmental concerns which bring socioeconomic problems. The pressure of coal on the current account deficit is much lower than oil and gas. There are attempts to use domestic reserves however environmental concerns should be addressed.

\section{References}

[1] Altinay, G. and Karagol, E. (2001) Electricity Consumption and Economic Growth Evidence from Turkey. Energy Economics, 27, 849-856.

https://doi.org/10.1016/j.eneco.2005.07.002

[2] Erbaykal, E. and Erman E. (2007) Turkiye'de Enerji Tuketiminin Ekonomik Buyume Uzerindeki Etkisi. Beykent Universitesi Sosyal Bilimler Dergisi, 1, 29-44.

[3] Kraft, J. and Kraft, A. (1978) On the Relationship between Energy and GNP. Newyork. Journal of Energy and Development, 3, 2.

[4] Mucuk, İ. and Uysal, D. (2009) Turkiye Ekonomisinde Enerji Tuketimi ve EkonomikBuyume, Maliye Dergisi, 157, 105-115.

[5] Narayan, P.K., and Smyth, R. (2009) Electricity Consumption, Employment and Real Income in Australia Evidence from Multivariate Granger Causality Tests. Energy Policy, 33, 1109-1116. https://doi.org/10.1016/j.enpol.2003.11.010

[6] Nasiru, I., Usman, H.M. and Saidu, A.M. (2014) Oil Consumption and Economic Growth Evidence from Nigeria. Bulletin of Energy Economics, 2, 106-112.

[7] Nonejad, M. and Fathi, S. (2014) A Survey of the Causality Relation Between EnergyConsumption and Economic Growth in Iran. International Journal of Management, Accounting \& Economics, 1, 15-27.

[8] Park, S. and Yoo, S.H. (2014) The Dynamics of Oil Consumption and Economic Growth in Malaysia, Energy Policy, 66, 218-223.

https://doi.org/10.1016/j.enpol.2013.10.059

[9] Sari, R. and Soytas, U. (2004) Disaggregate Energy Consumption, Employment and Income in Turkey. Energy Economics, 26, 335-344.

[10] Stambuli, B. (2014) Oil Consumption and Economic Growth Nexus in Tanzania Cointegration Causality Analysis. International Journal of Academic Research in Economic and Management Sciences, 3, 113-123.

[11] Topall, N. and Alagoz, M. (2014) Energy Consumption and Economic Growth in Turkey: An Empirical Analysis. Selcuk University Social Sciences Institute Journal, 32, 151-159. 
[12] Vlahinic, N. and Jakovac, P. (2014) Revisiting the Energy Consumption-Growth Nexus for Croatia: New Evidence from a Multivariate Framework Analysis. Contemporary Economics, 8, 435-452. https://doi.org/10.5709/ce.1897-9254.155

[13] Yapraklı, S. and Yurttançıkmaz, Z.C. (2012), Elektrik Tuketimi ile Ekonomik Buyume Arasindaki Nedensellik: Turkiye Uzerine Ekonometrik Bir Analiz. CU Íktisadi ve Ídari Bilimler Dergisi, 13, 195-215.

[14] Zhang, L.J. (2015) An Improved Method of Granger Causality Test and Application on the Stock Market Risk Transmission. Economic Computation and Economic Cybernetics Studies and Research, 49, 309-327. 